\title{
The effect of ionizing radiation and storage temperature on the post-harvest growth and some quality properties of mushrooms (Agaricus bisporus)
}

\section{IRRYSPINA SMIERZCHALSKA and ELŻBIETA WOJNIAKIEWICZ}

\author{
Research Institute of Vegetable Crops, 22 Lipca 1/3, \\ 96-100 Skierniewice, Poland
}

(Received: June 14, 1985)

\begin{abstract}
The effects of a dose of $2.0 \mathrm{kGy}(\mathrm{Co}-60)$ and three ranges of storage temperature $\left(0-4^{\circ} \mathrm{C}, 9-11^{\circ} \mathrm{C}, 18-19^{\circ} \mathrm{C}\right)$ on increasing the shelf-ifife and some quality properties of the mushrooms were investigated. The retardation of mushroom growth and ageing by ionizing radiation was estirated by measurements of the cap diameter, stem elongation, cap opening and discoloration of cap surface. The control of fungal and bacterial diseases was also evaluated. The effect of lower doses, 0.5 and $1.0 \mathrm{kGy}$, was compared at the storage temperature of $10^{\circ} \mathrm{C}$.

The irradiation of mushrooms soon after harvest and storage at temperatures of 10 and $16^{\circ} \mathrm{C}$ allowed the retention of quality and increased the shelf-life to 8 days; at $18-19^{\circ} \mathrm{C}$, to 6 days.
\end{abstract}

\section{INTRODUCTION}

Both increasing production of mushrooms and their perishable properties call for the more economical methods of post-harvest storage.

A review of the experiments carried out in the Netherlands, United States of America, Hungary and Czechoslovakia dealing with the irradiation method has been published (S mierzchalska and $\mathrm{Gu}$ bry now ic $z, 1979)$. The results encouraged checking the method under our conditions.

Studies were undertaken in the Isotopic Laboratory at the Department of Biology in 1979. They aimed to show the effectiveness of ionizing radiation on the retardation of mushroom growth and ageing depending on the storage temperature after irradiation. The effect of different doses was also investigated.

In addition to several quality properties, the control of fungal and bacterial diseases by ionizing radiation was also evaluated. 


\section{MATERIALS AND METHODS}

A number of experiments was carried out during 1979-1981 with mushrooms (Agaricus bisporus) to show the effectiveness of ionizing radiation at different storage temperatures. The experimental series included the following treatments:

- irradiation doses of 0 and $2.0 \mathrm{kGy}$; storage temperatures: $0-4^{\circ} \mathrm{C}, 9-11^{\circ} \mathrm{C}$, and $18-19^{\circ} \mathrm{C}$,

- irradiation doses of 0 and $2.0 \mathrm{kGy}$; storage temperatures: $10^{\circ} \mathrm{C}$ and $16^{\circ} \mathrm{C}$,

- irradiation doses of $0,0.5,1.0$ and $2.0 \mathrm{kGy}$; storage temperature $10^{\circ} \mathrm{C}$.

Each experimental series consisted of 3 or 4 experiments, started at one week intervals. The mushrooms were taken mostly from the first, second and third flushes. In each particular experiment the treatments were done in triplicate.

Mushrooms were delivered from the Experimental and Production Station for Edible Mushrooms in Skierniewice. In the first series, the strain used was Somycel 611, in the next two - Somycel 653. Mushrooms were gathered early in the morning, cleaned, selected and packed into small paper boxes.

Experimental mushrooms were at the "closed cup" stage (unbroken. velum) with diameters of $25-40 \mathrm{~mm}$, and stem length of a few millimeters. Twenty-two to thirty mushrooms were put into boxes; their fresh weight amounted to about $200 \mathrm{~g}$. The small boxes were placed into larger boxes in a single layer for transport and storage after irradiation. The small paper boxes, as well as the large ones, were imported from the Netherlands and are used for transportation of mushrooms abroad. When the big boxes with samples were stacked on each other, $90-100 \%$ $\mathrm{RH}$ was reached inside the small boxes $\mathrm{w}$ ith mushrooms.

Mushroom samples were brought by car to the Institute of Radiation Chemistry in Łódź (70 $\mathrm{km}$ from Skierniewice) and irradiated with gamma rays from a Co-60 source with an activity of about $740 \mathrm{TBq}$ (about $20 \mathrm{kCi}$ ). To absorb a dose of $2.0 \mathrm{kGy}$, the irradiation had to last $1 \mathrm{~h} 40 \mathrm{~min}$. The standard deviations for the applied doses were the following: $2.0 \pm 0.2 \mathrm{kGy} ; 1.0 \pm 0.1 \mathrm{kGy} ; 0.5 \pm 0.1 \mathrm{kGy}$. The temperature in the irradiation chamber was $18-20^{\circ} \mathrm{C}$.

The time between harvest and irradiation was very short; it ranged irom 5 to $7 \mathrm{~h}$. During transport the temperature varied from $10^{\circ} \mathrm{C}$ to $20^{\circ} \mathrm{C}$.

After returning to Skierniewice, the boxes with mushrooms were put and kept in a temperature in accordance with the experimental 
schemes. To eliminate the influence of transport conditions, boxes containing unirradiated mushrooms were also transported to Łódź and back to Skierniewice.

The retardation of mushroom growth and ageing was evaluated by measuring the increase of cap diameter, stem elongation, degrees of cap opening, percentage of mushrooms with open caps, discoloration of cap surface and sporulation.

The discoloration of caps was evaluated optically and in some experiments by using Hunter's Apparatus.

The sporulation was determined by the following test; after the storage period the mushrooms were kept in a thermostat at $21^{\circ} \mathrm{C}$.

In the experiments, the occurrence of bacterial and fungal diseases was expressed as the percentage of mushrooms infected.

Fresh weight losses were also determined.

The results were evaluated statistically; standard deviation and analysis of variance were calculated. The LSD values were established for the $5 \%$ confidence level.

The results are presented in the form of diagrams. The values are the average for the particular series.

\section{RESULTS}

\section{Effectiveness of irradiation with $2.0 \mathrm{kGy}$ at various storage temperatures}

Data presented in Figure 1 show that at a low storage temperature, $0-4^{\circ} \mathrm{C}$, there was no effect of irradiation with $2.0 \mathrm{kGy}$ on mushroom growth - cap size and stem elongation. The low temperature retarded mushroom growth effectively during 10 days of storage. The only difference observed was the better quality of the irradiated mushrocms at any evaluation time. After 10 days of storage the irradiated mushrooms were whiter and a higher percentage had closed caps.

The ionizing radiation retarded mushroom growth at the higher storage temperatures, $9-11^{\circ} \mathrm{C}$ and $18-19^{\circ} \mathrm{C}$.

At the temperature $9-11^{\circ} \mathrm{C}$, the irradiated mushrooms grew slower than unirradiated ones. Their cap diameters increased a bit only until the fourth day of storage (Fig. 1A). Later, they remained the same size from the fourth to eighth day of storage. The caps of unirradiated mushrooms increased until the eighth day of storage.

The stem elongation of the irradiated mushrooms stored at $9-11^{\circ} \mathrm{C}$ was also retarded in comparison with unirradiated ones (Fig. 1B); the differences are not statistically significant. 

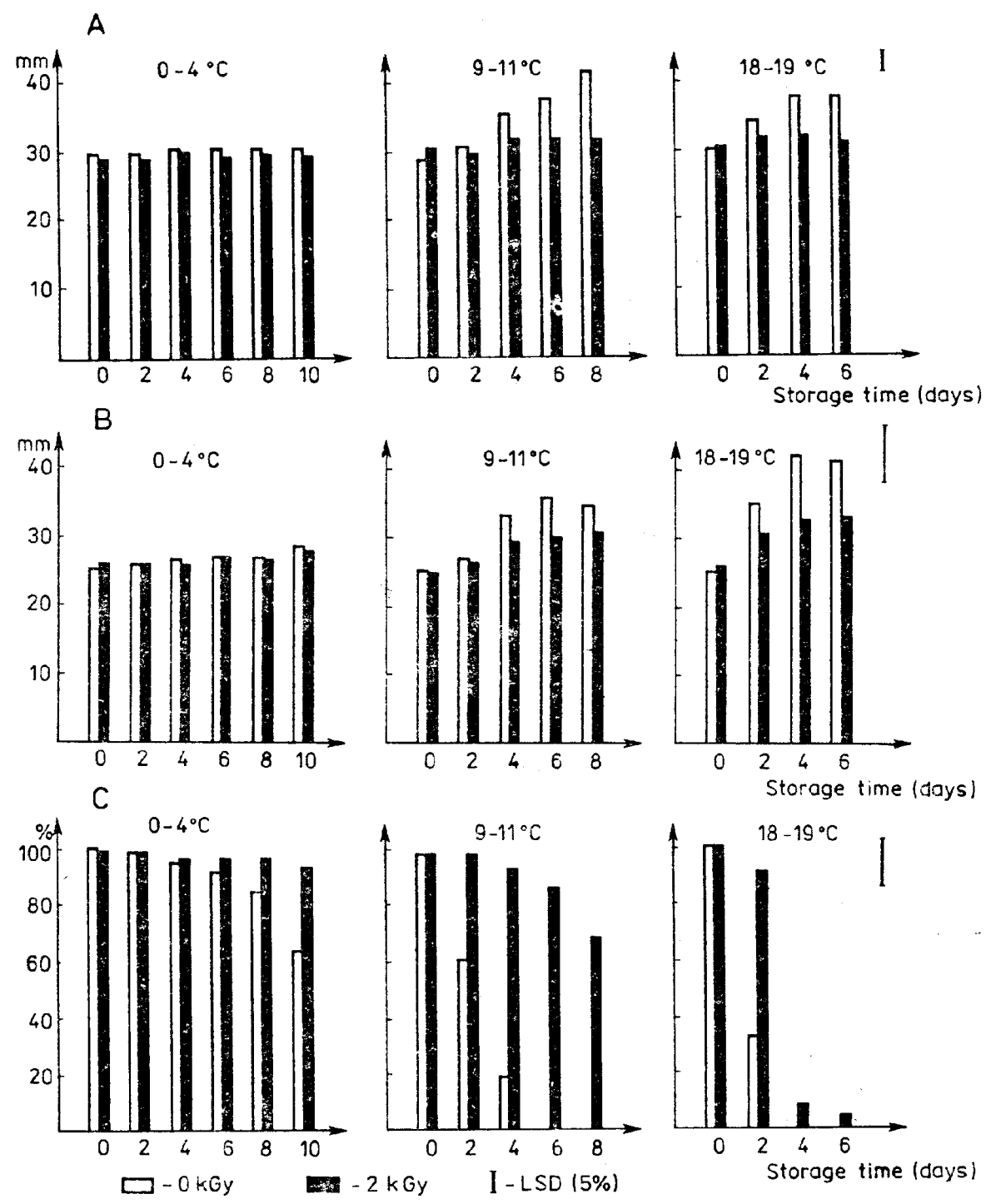

Fig. 1. Effect of ionizing radiation on retardation of mushroom growth at different storage temperatures; A - cap diameter. B - stem length, C - mushrooms with closed caps

The greatest differences between irradiated and unirradiated samples occurred in the cap opening of mushrooms at any time of evaluation (Fig. 1C). On the 4th storage day at $9-11^{\circ} \mathrm{C}$ about $90^{\circ} \%$ of irradiated mushrooms had closed caps, while at that time less than $20 \%$ of the unirradiated mushrooms had closed caps. After 6 storage days the caps of $80 \%$ of irradiated mushrooms remained closed, while caps of unirra- 
diated mushrooms were all open. The color and the other quality properties as well as lack of diseases received better evaluation in the case of irradiated mushrooms than unirradiated ones. After 8 days of storage the irradiated mushrooms were marketable, while unirradiated were not edible.

At a storage temperature of $18-19^{\circ} \mathrm{C}$ the differences between the irradiated and unirradiated mushrooms occurred earlier (Fig. 1), after only 2 stcrage days. The differences are especially great when the influence of irradiation on cap opening is compared. After 2 storage days at $18-19^{\circ} \mathrm{C}$, about $90 \%$ of irradiated mushrooms had closed caps, while only about $30 \%$ of the unirradiated mushrooms had closed caps. The unirradiated mushrooms stored at $18-19^{\circ} \mathrm{C}$ for 6 days deteriorated completely and were useless; they were over-grown and discolored, had dark gills and spreading spores, and were covered with molds and spots of bacterial diseases. At the same time the irradiated mushrooms were of much better quality, less grown and whiter; infection with diseases occurred in only $10 \%$ of the mushrooms.

The comparison of cap surface discoloration of irradiated and unirradiated mushrooms made on the basis of measurements with Hunter's Apparatus showed significant differences in favor of irradiated mushrooms.

Fresh weight losses during storage at various temperatures are shown in Figure 2. The irradiation did not influence the losses; they were affected mainly by storage temperature and increased significantly with

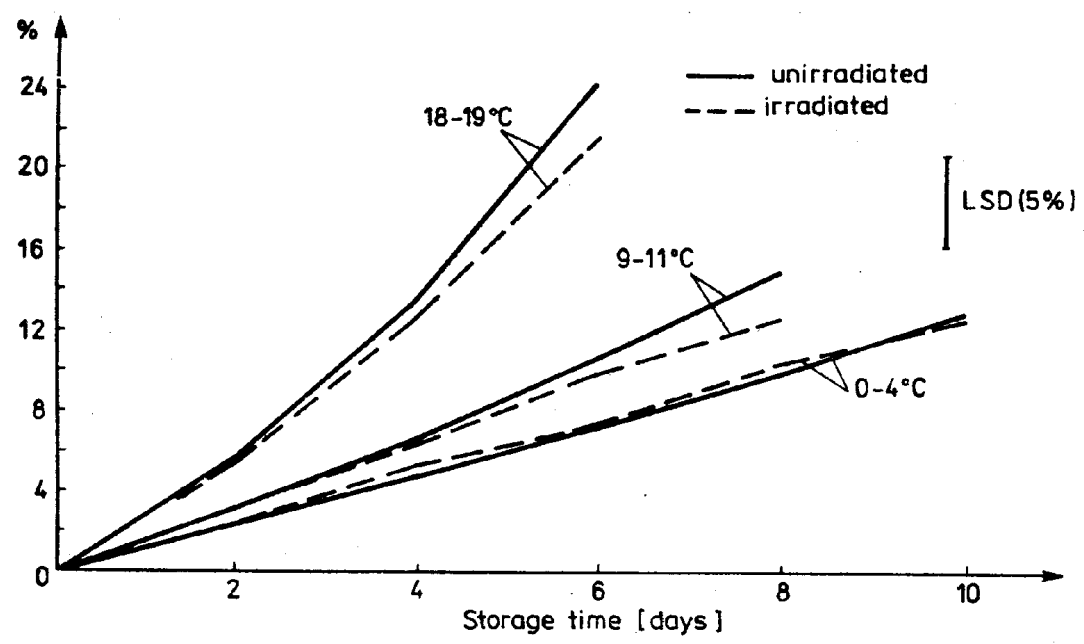

Fig. 2. Fresh weight losses of irradiated and unirradiated mushrooms stored at different temperatures 
increasing storage temperature. After 6 days of storage at $18-19^{\circ} \mathrm{C}$ the losses were twice as great as at $9-11^{\circ} \mathrm{C}$.

The results of further experiments (Fig. 3A, B, C) confirmed the effectiveness of the irradiation dose of $2.0 \mathrm{kGy}$ on the retardation of mushroom growth and quality preservation for storage temperatures $10^{\circ} \mathrm{C}$ and $16^{\circ} \mathrm{C}$. It can be stated that post-harvest mushroom growth occurred until the 5 th day; later it stopped. The irradiation retarded stem elongation more than cap size increase (Fig. 3A, B). Stem growth of unirradiated mushrooms was somewhat lower at $16^{\circ} \mathrm{C}$ than at $10^{\circ} \mathrm{C}$.
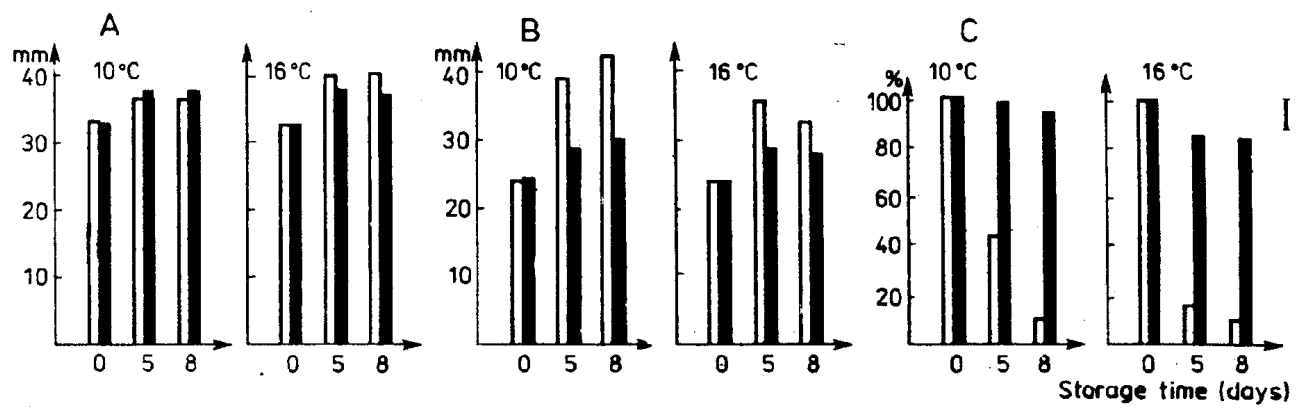

Fig. 3. Effect of ionizing radiation $(2.0 \mathrm{kGy})$ and stcrage temperatures on retardation of mushroom growth; A - cap diameter, B - mushroom height, $\mathrm{C}$ - mushrooms with closed caps

Similarly as in previous experiments, the dose of $2.0 \mathrm{kGy}$ affected significantly cap opening at both temperatures (Fig. 3C). After 8 days of storage at $10^{\circ} \mathrm{C}$, about $90 \%$ of irradiated mushrooms had their caps closed, while unirradiated ones had only about $10 \%$. The data for storage at $16^{\circ} \mathrm{C}$ are $80 \%$ and $10 \%$, respectively.

The occurrence of fungal and bacterial diseases (Fig. $4 \mathrm{~A}, \mathrm{~B}$ ) was markedly decreased by irradiation and strongly depended on storage temperatue, particularly in the case of fungal diseases. After 8 days of storage at $16^{\circ} \mathrm{C}$, the unirradiated mushrooms were all moldy while only $10 \%$ of the irradiated mushrooms were moldy. The dominant fungal disease was identified as Acremonium album. At a storage temperature of $10^{\circ} \mathrm{C}$, visible infection with fungal diseases was lower.

The occurrence of bacterial diseases was also affected by irradiation. The differences between the irradiated and unirradiated mushrooms were significant (Fig. 4B). The dominant bacterial disease was brown spots (Pseudomonas tolaasi). After 8 days of storage at $10^{\circ} \mathrm{C}$, less than $20 \%$ of the irradiated mushrooms were covered with brown spots, while about $70 \%$ of the unirradiated ones were covered with them. When stored at 

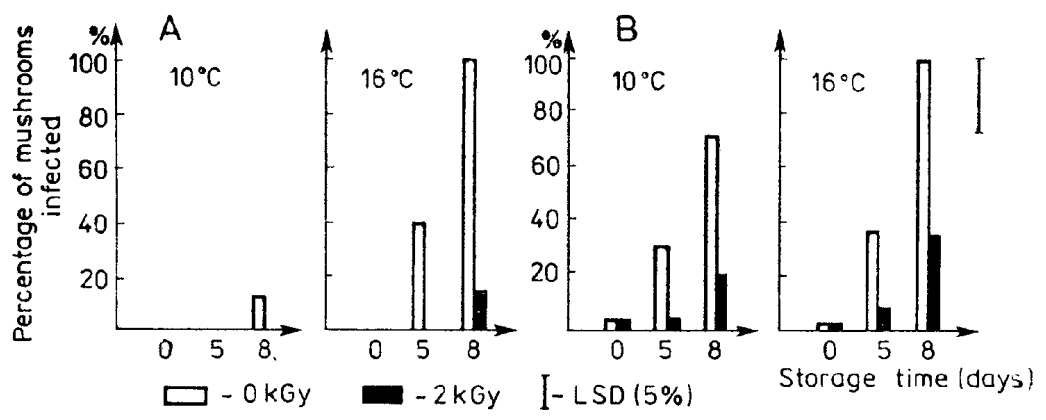

Fig. 4. Effect of ionizing radiation $(2.0 \mathrm{kGy})$ and storage temperatures on the infection of mushrooms caused by fungal (A) and bacterial (B) diseases

$16^{\circ} \mathrm{C}, 30 \%$ of the irradiated mushrooms were infected compared with $100 \%$ of the unirradiated mushrooms.

The measurements of fresh weight losses confirmed that the irradiation had no effect on them. Similary as in previous experiments, the losses depended on storage temperature. After 8 days of storage at $16^{\circ} \mathrm{C}$ the fresh weight losses were twice as great as at $10^{\circ} \mathrm{C}$.

\section{Effectiveness of lower radiation doses}

The results of the experiments with the doses of $0.5 \mathrm{kGy}$ and $1.0 \mathrm{kGy}$ carried out at storage temperature $10^{\circ} \mathrm{C}$ are given in Figures 5,6 and 7 . Irradiation did not affect the cap growth (cap diameter increase, Fig. 5A).

Visible differences, mostly statistically significant, occurred in the increase of elongation ( $\mathrm{Fig}$. 5B, C). The dose effect can be seen. The dose effect was also seen upon the examination of the influence of irradiation cn cap opening (Fig. 6). Generally, the dose of $1.0 \mathrm{kGy}$ gave similar
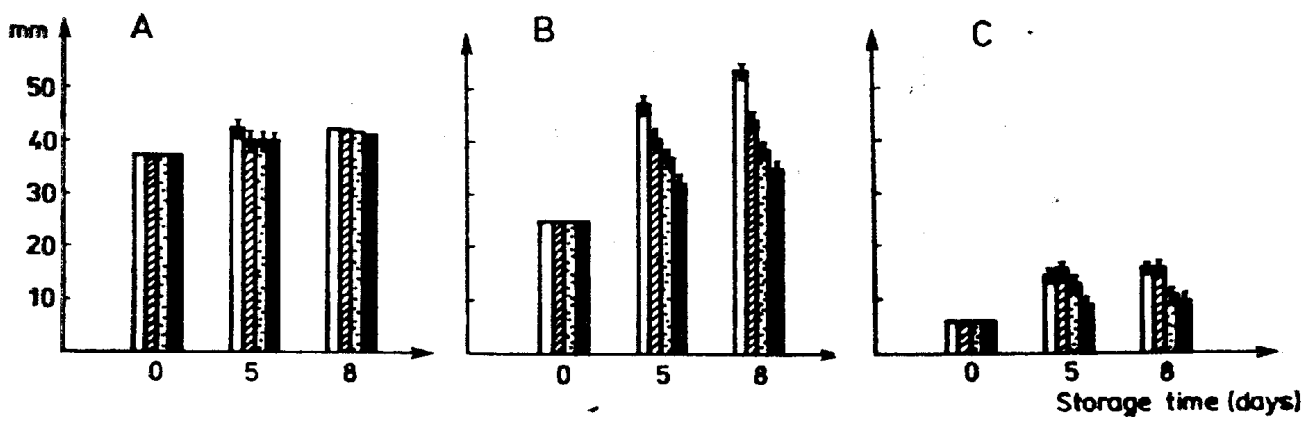

Fig. 5. Effect of various doses of ionizing radiation $(0,0.5,1.0,2.0 \mathrm{kGy})$ on retardation of mushroom growth at storage temperature $10^{\circ} \mathrm{C} ; \mathrm{A}$ - cap diameter, B mushroom height, $\mathrm{C}$ - stem length 


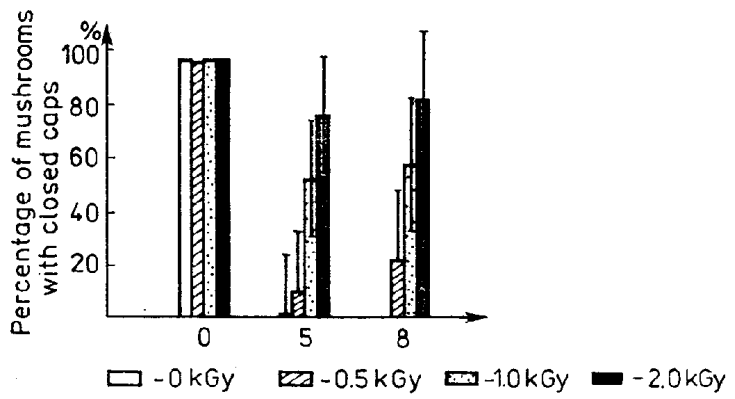

Fig. 6. Influence of various doses of ionizing radiation on retardation of mushroom cap opening

effects to the dose of $2.0 \mathrm{kGy}$. The dose of $0.5 \mathrm{kGy}$ was less effective.

The quality properties, color and texture, showed the dose effect too; higher doses increased retention of quality.

The test for sporulation of mushrooms indicated that all applied doses retarded it. No spore spreading was observed in irradiated mushrooms, even at the low dose of $0.5 \mathrm{kGy}$; unirradiated mushrooms readily spread off spores.

The occurrence of fungal disease (Acremonium album) and bacterial brown spots (Pseudomonas tolaasi) was strongly affected by irradiation (Fig. 7) and the dose effect was seen.

After 8 days of storage at $10^{\circ} \mathrm{C}, 50^{\circ} \%$ of the unirradiated mushrooms
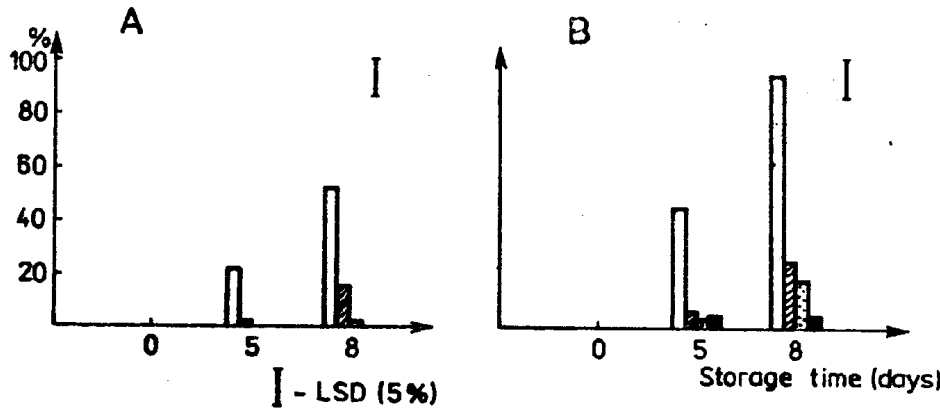

Fig. 7. Influence of various doses of ionizing radiation on the occurrence of mushroom diseases; A - fungal diseases, B - bacterial diseases

were covered with white mold (Acremonium album); only $10 \%$ of the mushrooms irradiated with the dose $0.5 \mathrm{kGy}$ were infected. At higher doses, $1.0 \mathrm{kGy}$ and $2.0 \mathrm{kGy}$, molding did not occur. All applied doses affected the occurrence of bacterial brown spots (Pseudomonas tolaasi). After 8 days of storage all the unirradiated mushrooms were covered 
with brown spots, while only $20 \%$ of the mushrooms irradiated with the dose of $0.5 \mathrm{kGy}$ were infected. Higher doses decreased the extent of bacterial infection; a low percentage of the mushrooms was infected.

\section{DISCUSSION}

The results presented confirm the fact that irradiation of mushrooms retards their growth and ageing. The effect is strongly dependent on the dose and thermal conditions of storage after irradiation. As a consequence of the retarded growth and maturity, the quality properties of mushrooms may be retained for a longer time, enabling the prolongation of storage time. In our experimental and storage conditions the dose of $2.0 \mathrm{kGy}$, applied within a few hours after harvest, on mushrooms at the "cup closed" stage and at a storage temperature of $10^{\circ} \mathrm{C}$ (at high humidity), caused an increase of shelf life to 8 days; similar storage time prolongation was obtained at $16^{\circ} \mathrm{C}$. At the storage temperature of 18 $19^{\circ} \mathrm{C}$, the prolongation of the shelf-life of irradiated mushrooms was limited to 6 days.

At the low storage temperature, $0-4^{\circ} \mathrm{C}$, an effect of irradiation with $2.0 \mathrm{kGy}$ on mushroom growth was not observed until 10 days of storage. This temperature retarded mushroom growth well. Only the quality of irradiated mushrooms was better in comparison with unirradiated.

Similar results were obtained in experiments carried out by a number of investigators. Some differences might be caused by different experimental conditions (mushrooms state, storage parameters, and irradiation technique).

The results of our experiments are similar to those obtained by $\mathrm{L}$ a nge rak (1971). He stated that irradiation with $2.0 \mathrm{kGy}$ and storage at $3-5^{\circ} \mathrm{C}$ increased the shelf-life by 10 days; storage at $8-10^{\circ} \mathrm{C}$ by 7 days, and at $20^{\circ} \mathrm{C}$ by 5 days. In experiments by $\mathrm{F}$ a r k a s (1975) irradiation with $3.0 \mathrm{kGy}$ and storage at $16-18^{\circ} \mathrm{C}$ (at $65 \% \mathrm{RH}$ ) increased the shelf-life to 3 days. $\mathrm{K}$ ova $\mathrm{s}$ and $\mathrm{Vas}$ (1974) increased the shelflife to 13 days by irradiation with $2.0 \mathrm{kGy}$ and storage at $6-8^{\circ} \mathrm{C}\left(65^{\circ} \%\right.$ $\mathrm{RH})$; at a higher temperature, $16-18^{\circ} \mathrm{C}$, the shelf-life increased to 11 days. In an earlier investigation by $\mathrm{St}$ a d e $\mathrm{n}$ (1965), mushrooms irradiated with $2.0 \mathrm{kGy}$, stored at $10^{\circ} \mathrm{C}$, kept closed caps for 12 days; the unirradiated mushrooms were all open after 7 days. $\mathrm{Ma} \mathrm{r} \mathrm{ka} \mathrm{k} \mathrm{is} \mathrm{(1968)}$ obtained similar results with the same dose when stored at $5^{\circ} \mathrm{C}$ for 12 days. S a lkova et al. (1978) reported that mushrooms irradiated with a dose of $2.0 \mathrm{kGy}$ and stored at $2{ }^{\circ} \mathrm{C}$ kept their quality for 20 days; at a storage temperature of $15^{\circ} \mathrm{C}$, quality was maintained for 7 days. But 
at the storage temperature of $24^{\circ} \mathrm{C}$, an effect of irradiation did not occur; irradiated mushrooms deteriorated as quickly as unirradiated ones.

Irradiation slowed the darkening processes, probably through the retardation of ageing. In all experiments we observed that irradiated mushrooms kept their whiteness for a longer period and at any evaluation time the difference was visible and verifiable by measurements using Hunter's Apparatus.

As a consequence of retarded growth, the irradiated mushrooms also kept their texture for a longer time. The influence of irradiation on maintaining the color was also reported by $\mathrm{Staden} \mathrm{(1965),} \mathrm{Gill} \mathrm{et}$ al. (1969), L a ngerak (1971), Kovaćs and V a s (1974 A, B), B a r$\mathrm{kai}-\mathrm{Golan}$ and $\mathrm{Padova}$ (1981). Some of these authors also demonstrated better texture of irradiated mushrooms after storage in comparison with unirradiated ones. They found no differences in flavor and taste between treated and untreated mushrooms.

In the investigation of the effectiveness of lower doses of irradiation we observed that the dose of $1.0 \mathrm{kGy}$ gave results approaching the results obtained with a dose of $2.0 \mathrm{kGy}$ when the storage temperature was $10^{\circ} \mathrm{C}$. The dose of $0.5 \mathrm{kGy}$ was less effective. The dose effect was observed on the growth parameters: mushroom height and cap opening.

$\mathrm{S} t$ a d e $\mathrm{n}$ (1965) looking for the most effective low radiation dose investigated a range of doses from $0.5 \mathrm{kGy}$ to $2.5 \mathrm{kGy}$. The influence on cap opening was the same at $1.0 \mathrm{kGy}$ and $2.0 \mathrm{kGy}$. Markakis (1968) stated that doses of $0.25,0.5$ and $1.0 \mathrm{kGy}$ similarly affected cap opening. Gill et al. (1969) found that low doses 0.1-0.5 kGy, were less effective; these doses influenced cap opening more strongly than stem elongation. The latter was affected by dose of $1.0 \mathrm{kGy}$ and higher. $\mathrm{M}$ a r$\mathrm{kak}$ is (1968), Kovaćs and Vas $(1974 \mathrm{a}, \mathrm{b})$ concluded that for unripe mushrooms, irradiated shortly after picking, the low dose (0.25 kGy) retarded mushroom growth effectively. According to $\mathrm{Fark}$ a s (1975) the dose $0.25 \mathrm{kGy}$ was effective for storage at temperature $5-8^{\circ} \mathrm{C}$ at $70-90 \% \mathrm{RH}$. S a l k ova et al (1978) regarded the doses $1.5-3.0 \mathrm{kGy}$ as most effective. Barkai-Golan and $\mathrm{Padova}$ (1981) stated that the dose of $0.5 \mathrm{kGy}$ and higher inhibited cap opening, stalk elongation at storage temperature $15^{\circ} \mathrm{C}$.

In our experiments all applied doses $(0.5,1.0$ and $2.0 \mathrm{kGy})$ retarded the sporulation of mushrooms. Ionizing radiation may influence this phenomenon in various ways. Kovać S (1982 a, b) stated that irradiation slowed down the ageing processes, the cytokinin activities as well as sporulation. As the result of irradiation, the spore count decreased as a function of the dose; after a dose of $2.0 \mathrm{kGy}$ and 5-days storage, the spore count did not exceed the original value, while in non-treated 
mushrooms the spore count increased five-fold. Similarly, spores of treated mushrooms maintained their original color while non-treated ones became entirely dark.

Another radiation effect indicated in our experiments worth stressing is that irradiation strongly reduced the incidence of fungal and bacterial diseases. This fact might be of importance in storage problems and deserves more attention.

It was already reported by $\mathrm{St}$ a d e $\mathrm{n}(1965,1966)$, that irradiated mushrooms remained mold-free during storage. Gill et al. (1969) also observed less mold growth on irradiated mushrooms. $\mathrm{S}$ a $1 \mathrm{k}$ o va et al. (1978) showed the decrease in pathogenic fungal spores of artificially infected mushrooms after irradiation with 2.0 and $3.0 \mathrm{kGy}$.

As a consequence of mushroom growth retardation and significant control the occurrence of fungal and bacterial diseases, in our experiments irradiation with a dose of $2.0 \mathrm{kGy}$ allowed the self-life of mushrooms to increase to 8 days at storage temperature of $10^{\circ} \mathrm{C}$ and $16^{\circ} \mathrm{C}$, and to 6 days at storage temperature of $18-19^{\circ} \mathrm{C}$.

The practical application of the irradiation method in mushroom storage may be of value in the case when cold storage (near $0^{\circ} \mathrm{C}$ ) would be more expensive than the treatments with ionizing radiation and storage at $10^{\circ} \mathrm{C}$ and even higher temperatures till $16^{\circ} \mathrm{C}$. These temperatures are available in common storage rooms, ventilated with outside air, during colder seasons.

\section{Acknowledgment}

The authors are grateful to the Department of Microbiology of the Research Institute of Vegetable Crops in Skierniewice for help in the identitication of fungal diseases of mushrooms.

We also thank Miss M. Walczak and Ing. G. Swiderski for technical assistance during performence of the experiments.

\section{REFERENCES}

Barkai-Golan R., Padova R., 1981. Extending the shelf-life of cultivated mushrooms by gamma irradiation. Hort. Abst. 51,3 (poz. 1718).

Farkas J., 1975. Present status and prospects for the commercialization in Hungary of irradiated food items for human consumption. Requirements for the Irradiation of Food on a Commercial Scale. Proc. of Panel, Vienna 1975. IAEA, op. 37-57.

Gill W. I., Nicolas R. C., Markakis P., 1969. Irradiation of cultured mushrooms. Food Technology 23: 385-388.

Kovaćs E., Vas K., 1974a. Effect of ionizing radiation on some organoleptic characteristics of edible mushroom. Acta Alimentaria 3: 11-17. 
Kovaćs E., Vas K., 1974b. Effect of ionizing radiation on post-harvest ripening processes of cultured mushrooms (Agaricus bisporus) with special references to the rates of respiration and of ethylene production. Acta Alimentaria 3: 19-25.

Kovaćs E., 1982a. Cytokinin activity of Agaricus bisporus. Acta Alimentaria 11: 169-178.

Kovaćs E., $1982 \mathrm{~b}$. Combined effect of kinetin and radiation treatment on the cap opening of Agaricus bisporus. Acta Alimetaria 11: 179-187.

Langerak D. J., 1971. The influence of irradiation and packaging upon the keeping quality of fresh mushrooms. Proc. Mushrooms Science 8: 221-230.

Markakis P., 1968. Irradiation of mushrooms. Mushrooms News 17: 8-11.

Salkova Z., Kubin K., Stanek M., Horaćek P., 1978. Present status of food irradiation in Czechaslovakia. Proc. of Symp. Food Preservation by Irradiation, Wageningen IAEA 1: 43-51.

Staden O. L., 1965. Radiation preservation of fresh mushrooms. Mushroom Science 6: 457-461.

Staden O. L., 1966. Experiences with the irradiation of vegetables in the Netherlands. Proc. of Symp. Food Irradiation, IAEA, pp. 609-617.

Smierzchalska K., Gubrynowicz E., 1979. Stosowanie promieniowania jonizującego $w$ przechowalnictwie pieczarek. Post. Nauk Rol. 2: 67-80.

Wpływ promieniowania jonizującego i temperatury przechowywania na wzrost i jakość pieczarek (Agricus bisporus)

\section{Streszczenie}

W latach 1979-1981 przeprowadzono doświadczenia ścisłe nad wpływem promieniowania jonizującego dawki $2,0 \mathrm{kGy}$ i różnych temperatur przechowywania grzybów po napromieniowaniu na hamowanie procesów wzrostu i starzenia się grzæbów. Badano również skuteczność mniejszych dawek 0,5 i 1,0 kGy.

Świeżo zebrane pieczarki dobrej jakości napromieniowywano w terminie 5-6 godzin po zbiorze, dawką $2,0 \mathrm{kGy}$, następnie umieszczono $\mathrm{w}$ różnych temperaturach. Efekt zastosowanej dawki zależal w dużym stopniu od temperatury przechowywania grzybów. W temperaturze $0-4^{\circ} \mathrm{C}$ był najmniej widoczny. Taka temperatura hamowała wzrost pieczarek zupełnie dobrze w ciągu 10 dni. Jednakże grzyby napromieniowane charakteryzowały się lepszą jakością, były bielsze i większy procent miał zamknięte kapelusze.

W wyższych temperaturach przechowywania pieczarek wplyw napromieniowania wystąpil wyraźniej. Dawka 2,0 kGy przy przechowywaniu w temperaturze $10^{\circ} \mathrm{C}$ hamowała wzrost elongacyjny, przyrosty średnicy kapeluszy i ich otwieranie, a także ciemnienie i zarodnikowanie. Zmniejszała również stopień porażenia pieczarek chorobą bakteryjną (Pseudomonas tolaasi) i grzybową (Acremonium album).

Podobne wyniki uzyskano przy przechowywaniu w temperaturze $16^{\circ} \mathrm{C}$.

W wyższych temperaturach $18-19^{\circ} \mathrm{C}$ efekt napromieniowania dawką $2,0 \mathrm{kGy}$ był również widoczny, z tym, że pieczarki znacznie szybciej ulegały niekorzystnym zmianom.

Poprzez zahamowanie procesów wzrostu pieczarek i rozwoju chorób bakteryjnych i pleśni, napromieniowanie dawką $2,0 \mathrm{kGy}$ przedłużalo okres składowania do 8 ani, gdy pieczarki przechowywano $w$ temperaturze $10-16^{\circ} \mathrm{C}$, i do $6 \mathrm{dni}$, gdy 
przechowywano je w temperaturze $18-19^{\circ} \mathrm{C}$. W tym czasie pieczarki nienapromieniowane były bardzo zlej jakości i nie nadawały się do spożycia.

Mniejsza dawka promieniowania jonizującego $1,0 \mathrm{kGy}$ i przechowywanie $w$ temperaturze $10^{\circ} \mathrm{C}$, wykazywala działanie zbliżone do dawki $2,0 \mathrm{kGy}$. Dawka $0.5 \mathrm{kGy}$ była mniej skuteczna. Wszystkie stosowane dawki promieniowania jonizującego hamowały osypywanie zarodników.

Praktyczne zastosowanie metody radiacyjnej w przechowywaniu pieczarek może mieć znaczenie, gdy przechowywanie w niskich temperaturach okaże się kosztowniejsze niż napromieniowanie grzybów i przechowywanie $w$ temperaturze $10^{\circ} \mathrm{C}$, a nawet wyżsych. Takie temperatury panują $u$ nas $w$ zwykłych przechowalniach w ciągu chłodniejszych miesięcy wiosny i jesieni. 